\title{
Solid-State Fermentation of Banana Peels Potential Study for Feed Additive
}

\author{
Akbarningrum Fatmawati*, Tuani Lidiawati, Stephen Hadinata, Mikhael Adiarto \\ University of Surabaya, Chemical Engineering Department, Jl. Raya Kalirungkut Surabaya, Indonesia
}

\begin{abstract}
Agricultural solid wastes present abundantly on earth as crops harvesting as well as processing are countinuesly run. Banana peels are one of agricultural solid wastes produced anywhere the banana processing presents. The peels present abundantly in tropical countries such as Indonesia. The carbohydrate content of banana peels make it useful for the production of many chemicals, including feed. Meanwhile the large need in feed in farming including fish farming could prevent farmer to obtain substantial profit. This research studied the possibility of banana peel as one of abundant Indonesian agricultural solid waste to be utilized as fish feed which is known requiring certain level of protein content. This was done by fermenting the peels in fixed bed reaction mode using surface aeration and non-aeration. The fermentation was conducted using yeast Saccharomyces cerevisiae Y1536 and Rhizopus Oryzae FNCC 6157. The reaction time was varied for 1,3 , and 5 days. The important parameters studied were protein contents, and amylase activity of the fermented banana peels. Despite aeration indicated more operational cost, it showed significant impact on the fermentation of banana peels. The best condition for fermentation using Saccharomyces cerevisiae Y1536 were 5 day fermentation with surface aeration which result in the increase of protein content up to $4.05 \%$, the decrease of fiber content up to $1.08 \%$, and amylase activity of $9.99 \mathrm{DP}$. Whilst the fermentation using Rhizopus Oryzae FNCC 6157 obtained its best result at 1 day fermentation with aeration, which are protein content increase up to $4.04 \%$ and fiber content decrease up to $0.69 \%$. However, the fermentation using this mold showed its best amylase activity result of $12.75 \mathrm{DP}$ at 5 day surface aerated fermentation.
\end{abstract}

\section{Introduction}

Waste produced from domestic, agriculture, and industrial activity has found causing many environemtal and health problems. Agricultural activities produces several waste including solid wastes, which in spite of causing environmental and health problems, they store economical potential to be transformed either chemically or non chemically into more beneficial products. Agricultural wastes which can be liquid, slurries or solids, are byproducts of growing and first processing of raw agricultural products such as fruit and vegetables, crops, meat and poultry as well as dairy products. Manures, fertilizers, and residues from slaughterhouse are also included as agricultural solid wastes [1]. Currently, many researches have attempted to utilise agicultural solid wastes to produce more valuable products and improve economy such as fired clay materials for building manufacturing, green desiccants in desiccantcooling systems, biofuels, bio-oil and char, and animal feed [2-6]. Generally agricultural wastes still contain useful nutrition components which are good for animal consumption. The potential of agricultural solid waste

\footnotetext{
* Corresponding author: akbarningrum@staff.ubaya.ac.id
}

for animal feed should be encouraged because of its benefit for both environment and the farmers.

In fish farming activities, the productivity of fish farmers is usually constrained by production cost where the feed cost can cover up to $50-80 \%$ of the total operational cost [7-9]. Protein is the main ingredient of the commercial diet of fish which constitutes $40-56 \%$ of the diets [10-11]. Many kinds of fermented fiberrich agricultural waste had been used for fish or shrimp feed additives such as papaya processing waste, corncob, rice husk and apple pomace [9, 12-14]. This carbohydrate-rich and low protein content agriculture wastes can be low cost fish energy source. However, carbohydrate amylolytic activity in carnivorous fish is lower than herbivorous fish [15]. Therefore, adding amylase activities on the carbohydrate feed will be advantageous.

Nutrient enrichment had been attempted by fermentation process which can increase protein content, required metabolic enzymes, and pathogenic bacteria inhibitory substance. Several fungi had shown to have either amylolytic or cellulolytic activities and therefore can be used to ferment carbohydrate-rich wastes while 
after fermentation they can provide protein sources needed for feed component. Some fungi such as Saccharomyces cerevisiae, Candida utilis, Aspergillus niger, and Rhizopus oligosporus have been known to be able to increase the protein content of biomass through fermentation [9]. Fermented corn-cob by mold consortium consisting of Trichoderma viridae, Trichoderma reesei, Aspergillus oryzae, and Rhizopus oligosporus had been used in feed formulation of Java barb fish and had been shown to increase the growth of Java barb [13]. Yeast protein is easily digestible and widely used for fish and shrimp feed supplement which in spite of providing protein source, it can enhance immune system and stimulating bacterial disease resistance [12]. When used as feed additive, the increased protein content of apple pomace after fermentation using $G$. butleri had been able to increase $44 \%$ in body mass of fish [16].

This research attempted to investigate the effect of solid-state fermentation of abundantly available waste banana peels by fungi Saccharomyces cerevisiae and Rhizopus oryzae on the protein and fiber content as well as the amylase activity of the peels in order to see its potential for fish feed additive. Solid-state fermentation itself has many applications including production of a large number of enzymes used in feed industry [17] The expected results were the increase of protein content of the banana peels and the availability of amylolitic activities of fermented banana peels.

\section{Materials and Methods}

\subsection{Materials and Preparation Stage}

The banana peels used in this research is from the species of Musa acuminate or Musa balbisiana or in Indonesian name, Pisang Kepok. The peels were collected locally from market and banana processing food seller. Immediately after collection, the peels were washed and cut into small size $(1 \mathrm{x} 0.2 \mathrm{~cm})$. The protein and fiber content of the peels were analyzed before fermentation.

There were two types of fermentation microorganism used in this research. The first type is yeast Saccharomyces cerevisiae Y1536 obtained from Institute Pertanian Bogor culture collection (IPBCC) while the second type is mold Rhizopus oryzae FNCC 6157 obtained from Food and Nutrition Development and Research Center (FANDARC), Gadjah Mada University (UGM). The fungi cultures were cultivated using potato dextrose agar (PDA).

\subsection{Fermentation Stage}

Prior to fermentation, the fungi cultures being used in the fermentation stage were transfered into $25 \mathrm{~mL}$ potato dextrose broth (PDB). The broths were shaken for 24 hours at speed of $150 \mathrm{rpm}$ using incubator shaker.

The fermentations were conducted using tray solidstate bioreactors set up from Erlenmeyer flask in which the banana peels were stacked. As much as 225 grams of banana peel was firstly steamed for 30 minutes inside Erlenmeyer flask. It is then cooled and inoculated with
24 hour broth innoculum in biological safety cabinet to prevent contamination. The fermentation system set up is shown on Fig 1. This fermentation was conducted with and without aeration. To prevent contamination from outside air, membrane filters were mounted on the top of the Erlenmeyer flasks. The reaction time was varied 1, 3, and 5 days. At the end of fermentation, the peels were analyzed for the protein and fiber content as well as amylase activity.

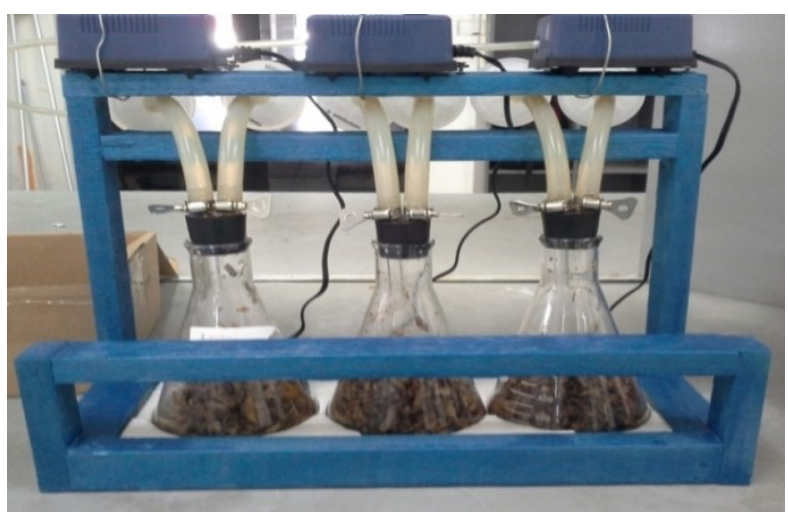

Fig. 1. Solid-state fermentation set up

\subsection{Chemical and Biological Analysis}

The protein contents of the fermented banana peels were analyzed using total nitrogen (Kjelhdal method). The fiber contents were analyzed using fiber anaylisis by SNI 01-2891-1992. The amylase activities of the fermented banana peels were assayed using method by Fuwa (1954) [18]. The method was colorimeterically and the activity was expressed as dextrinising power (DP). Principally the substrate for dextrinising power determination used was commercial cassava amylose which was prepared according to Fuwa method. The values of DP were measured by the change of blue values of amylose-iodine complexes. Amylase unit (1 DP) was defined as the amount of amylase which would produce 10 percent fall in blue colour intensity of amylase-iodine complexes.

\section{Results and Discussions}

The locally collected banana peels were analysed for the total carbohydrate, fiber, lipid, protein, water, and ash contents. The result showed that the banana peels studied contained 79.59-85.66 \% water. By dry basis, the peels also contained $55.05-58 \%$ total carbohydrate, $6.5-8.18 \%$ fiber, $7.36-12.23 \%$ lipid, $2.08-3.18 \%$ protein, and $13.97-20.24 \%$ ash. The result showed that the peels were rich in carbohydrate and were very suitable for energy sources. However, in order to be used as fish feed additives, effort must be done to improve their protein content as well to decrease the fiber contents. These can be achieved through fermentation. The process of fermentation by amylase producing fungi can also produce amylase enzyme which may be needed for increasing feed digestion rate of fish. 


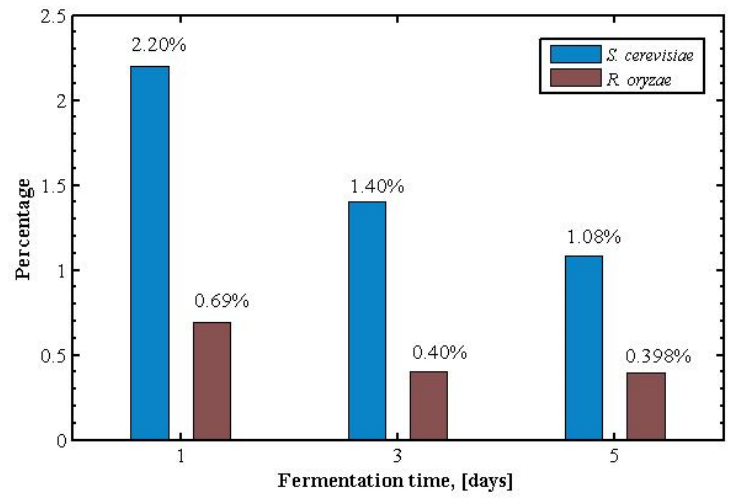

Fig. 2. Fiber content with aeration

The fiber contents resulted after fermentation is shown on Fig. 2 for aerated fermentation and Fig. 4 for non-aerated fermentation. While the protein content after fermentation is shown on Fig. 3 for aerated fermentation and Fig. 5 for non-aerated fermentation. From Fig.2, it is shown that the Rhizopus oryzae FNCC 6157 can decrease fiber faster and higher than Saccharomyces cerevisiae Y1536. It is understood that mould produces hydrolytic enzymes very well and better than yeast. By comparing Fig. 2 and Fig. 4, it can be said that aeration affected fiber decrease in the fermentation of banana peels by Saccharomyces cerevisiae and Rhizopus oryzae. This aeration increased the growth rate of those fungi and therefore increased the production of cellulase, fiber hydrolyzing enzyme.

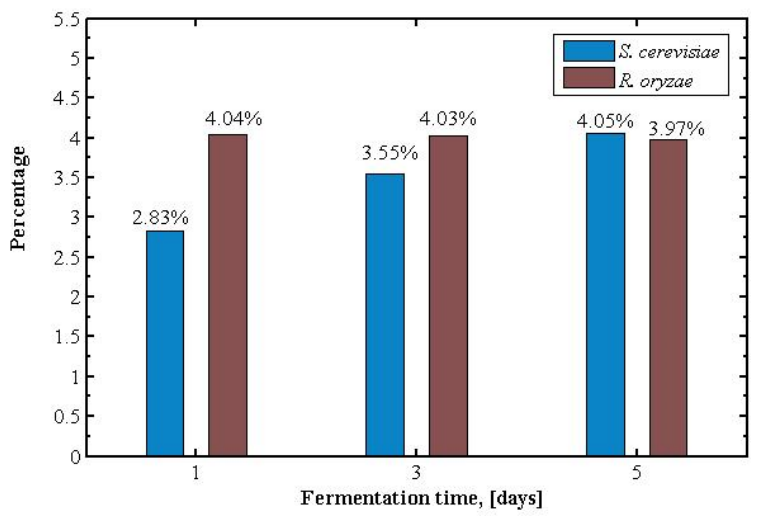

Fig. 3. Protein content with aeration

Fig. 3 and Fig. 5 presents the protein content of the banana peels after fermentation with aeration, and without aeration, respectively. The protein content increases with fermentation time. The figures also show that Rhizopus oryzae fermentation caused protein increase higher than Saccharomyces cerevisiae. This protein content increased because the fungi grew and used the banana peels as substrate, broke down the complex carbohydrate of the peels and synthesized protein as the component of fungi cell. The increase of protein content of banana peels made them potential to be used as animal feed additive, including fish feed additive.

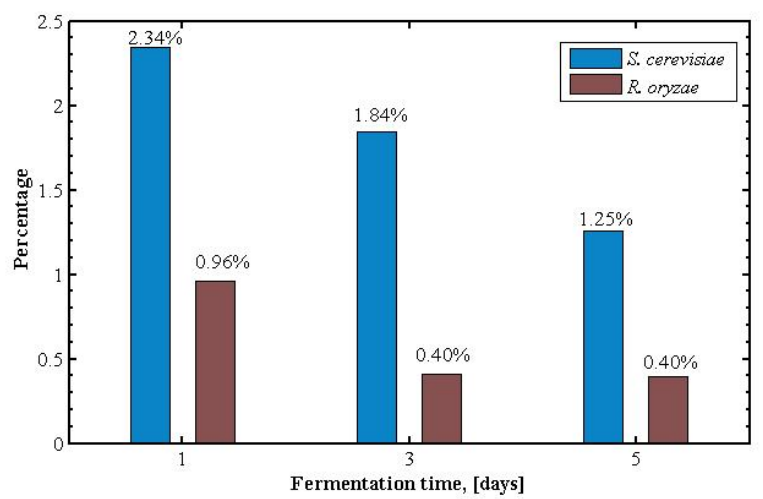

Fig. 4. Fiber content without aeration

The protein content increase was higher in fermentation with aeration compared to without aeration for each of the fungi because aeration favored the fungi growth. In the result of this research, it also can be seen that the highest protein content can be achieved up to $4 \%$ for 3 day aerated fermentation by $R$. oryzae. Higher protein content improvement can be achieved by lengthening the fementation time by $S$. cereviae.

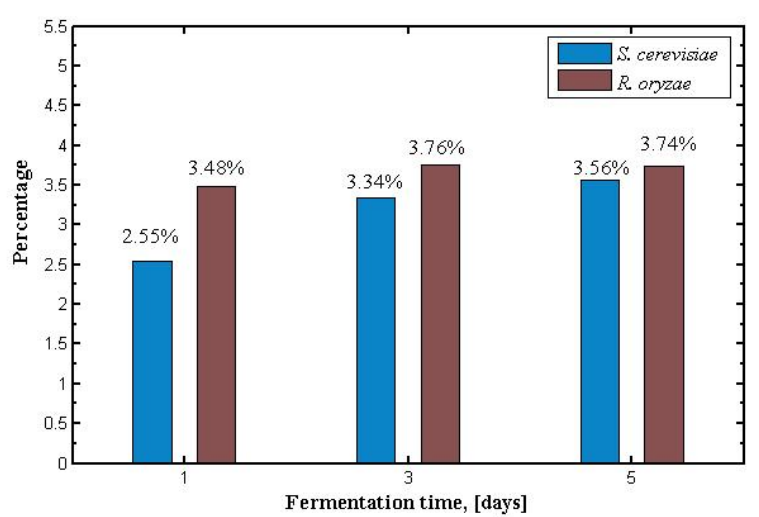

Fig. 5. Protein content without aeration

The amylase activity profiles after fermentation with and without aeration are shown in Fig. 6 and Fig. 7. The activity increased with fermentation time for each of the fungi because this enzyme was needed for their growth on banana peels which are composed mostly by starch.

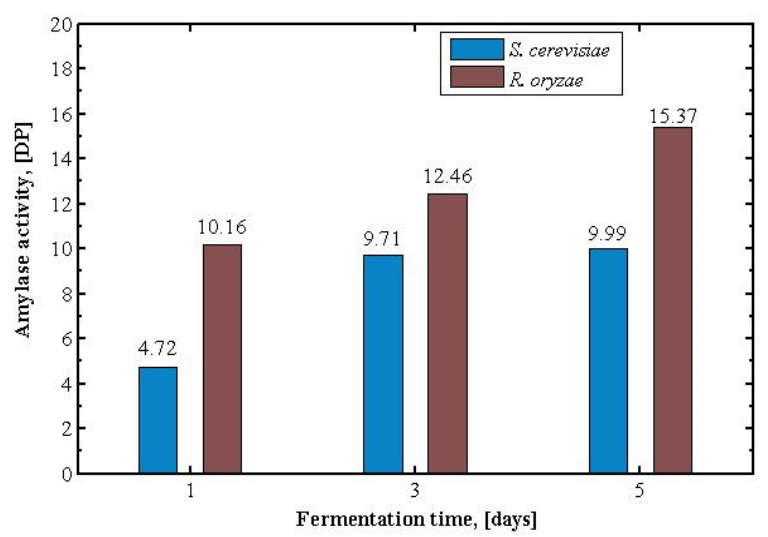

Fig. 6. Amylase activity result with aeration 
The amylase activity produced by Rhizopus oryzae was higher than that produced by Saccharomyces cerevisiae. That is the reason for the higher growth rate of $R$. oryzae which cause the higher protein content and the lower fiber content resulted from Rhizopus banana peel fermentation as depicted from previous figures. The highest amylase activity was achieved by 5 day aerated fermentation by Rhizopus oryzae which resulted as high as 15.37 DP. As Comparison, $1 \mathrm{~mL}$ Taka amylase resulted in 6.5 DP [18].

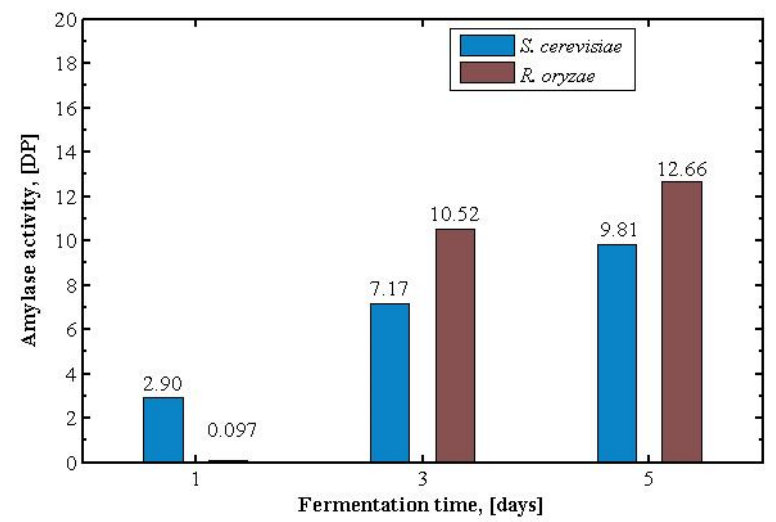

Fig. 7. Amylase activity result without aeration

The results has shown the potential usage of fermented banana peel as fish feed additive according to the increasing protein content, decreasing fiber content amylolitic enzyme to increase feed digestion. Previous publications have also shown that mixture of fungi such as T. viridae, T. reseei, A. oryzae, and Rhizopus oligosporus can ferment corn-cob to produce organic acid (citric, pantoteni, acetic and lactic), fatty acids, glucose, vitamin, mineral and various enzymes (lipase, protease and cellulase) [13]. Living cultures of Zygomycetes including Rhizopus oryzae have been used as probiotic organism to prevent fish infectious disease [19]. In spite of that, Saccharomyces cerevisiae is included as authorized probiotic in feeding stuffs under Council Directive 70/524/EEC [20]. Higher protein content from banana peel fermentation than obtained in this research could be achieved combining with other molds or with S. cerevisiae and other probiotic microorganisms in the future.

\section{Conclusions and Recommendations}

Banana peels fermentations by Saccharomyces cerevisiae Y1536 and Rhizopus oryzae FNCC 6157 had shown their potential as fish feed additive because of the increasing protein content and decreasing fiber content after fermentation. The fermentation also showed the presence of amylase activity needed for fish feed digestion. Banana peels fermentation by Rhizopus oryzae FNCC 6157 resulted in better protein increase, fiber decrease as well as amylase activity.

\section{References}

1. A.D. King Jr., A.D. Hocking, and J.I. Pitt, Dichloran-Rose-Bengal Medium for Enumeration of moulds from Foods. Applied and Environmental Microbiology, 37(5), 959-964, (1979)

2. O. Kizinievič, V. Kizinievič, I. Pundiene, D. Molotokas, Eco-friendly fired clay brick manufactured with agricultural solid waste. Civil and Mechanical Engineering, 18 (4), 1156-1165. (2018)

3. N. Asim, Z. Emdadi, M. Mohammad, M.A. Yarmo, K. Sopian, ReviewAgricultural solid wastes for green desiccant applications: an overview of research achievements, opportunities and perspectives. Journal of Cleaner Production, 91, 26-35, (2015)

4. P.K. Swain, Utilisation of Agriculture Waste Products for Production of Bio-Fuels: A Novel Study. Materials today: Proceedings, 4 (11) (part 3), 11959-11967, (2017)

5. I. Hawash, J.Y. Farah, G. El-Diwani, Pyrolysis of agriculture wastes for bio-oil and char productions. Journal of Analytical and Applied Pyrolysis, 124, 369-372 (2017)

6. O.O. Oduguwa, M.O. Edema, A.O. Ayeni, Physico-chemical and microbiological analyses of fermented corn cob, rice bran and cowpea husk for use in composite rabbit feed. Bioresource Technology 99, 1816-1820. (2008)

7. A.F.M. El-Sayed, Alternative Dietary protein sources for farmaed tilapia, Oreachromis spp. Aquaculture, 149-168, (2002)

8. F.A. Masoodi, B. Sharma G.S. Chauhan, Use of Apple Pomace as Source of Dietary Fiber in Cakes. Plant Foods for Human Nutrition, 57, 121128, (2002)

9. G.S. Dhillon, S. Kaur, K.S. Brar, Perspective of Apple Processing Wastes as Low-Cost Substrates for Bioproduction of High Value Products: A Review. Renewable and Sustainable Energy Reviews, 27, 789-805, (2013)

10. V.T. Namulawa, C.D. Kato, J. Rutaisire, P.J. Britz, N. Beukes, B.I. Pletschke, C. Whiteley, Enzyme Activity in The Nile perch Gut: Implications to Nile perch Culture. International Journal of Fisheries and Aquaculture, 5(9), 221-228. (2013)

11. S. Mukherjee, D. Parial, N. Khatoo, A. Chaudhuri, S. Senroy, S. Homechaudhuri, and R. Pal, 'Effect of formulated algal diet on growth performance of Labeo rohita Hamilton.' J. Algal Biomass Utln., 2(4), 1-9, (2011)

12. H.Y. Kang, P.Y. Yang, W.G., Dominy, C.S. Lee, Bioprocessing papaya processing waste for potential aquaculture feed supplement Economic and nutrient analysis with shrimp feeding trial. Bioresource Technology, 101, 7973-7979, (2010)

13. R. Rostika, R. Safitri, Influnce of Feed Containing Corn Cob was Fermented by Trichoderma sp, Aspergillus sp. And oligosporus to Rate of 
Growth of Java Barb (Puntius gonionitus). APCBEE Procedia, 2, 148 - 152. (2012)

14. A.A. Zaid, O.G. Taiwo, Comparative Utilisation of Biodegraded Rice Husk ini Diet of Clarias gariepinus. Journal of Fisheries and aquatic science, 3(5), 312-319, (2008)

15. M.C. Hidalgo, E. Urea and A. Sanz, Comapartive study of digestive enzymes in fish with different nutritional habits. Proteolytic and amylase activities. Aquaculture, 170, 267-283, (1999)

16. F. Vendruscolo, R.C. da Silva, E. Esposito, and J.L. Nienow, Protein Enrichment of Apple Pomace and Use in Feed for Nile Tilapia. Applied Biochemistry and Biotechnology, 152, 74-87, (2009)
17. L. Thomas, C. Larroche, and A. Pandey, Current Developments in Solid-State Fermentation. Biochemical Engineering Journal, 81, 146-161, (2013)

18. H. Fuwa, A New Method for Microdetermination Of Amylase Activity By The Use Of Amylose As The Subtrate. The Journal of Biochemistry, 41(5), 583-603, (1954)

19. L.B. Edebo, Zygomycetes for Fish Feed. US Patent No. 2009/0136617 A1

20. P. Pandiyan, D. Balaraman, R. Thirunavukkarasu, E. G. J. George, K. Subaramaniyah, S. Manikkam, B. Sadayappan, Probiotics in aquaculture, Drug Invention Today. 5(1), 55-59, (2013) 